L.M. Sugralina ${ }^{1}$, A.V. Omasheva ${ }^{1}$, L.K. Salkeeva ${ }^{1}$, A.S. Olzhabayeva ${ }^{1}$, Ye.V. Minayeva ${ }^{1}$, Ye.K. Taishibekova ${ }^{1}$, A.K. Salkeeva ${ }^{2}$, G.G. Baikenova ${ }^{3}$

${ }^{I}$ Ye.A. Buketov Karaganda State University, Kazakhstan;

${ }^{2}$ Karaganda State Technical University, Kazakhstan;

${ }^{3}$ Karaganda Economic University of Kazpotrebsoyuz, Kazakhstan

(E-mail:sugralinalm@yandex.ru)

\title{
Novel polyesters based on nitrogen-containing heterocycles: synthesis and research
}

\begin{abstract}
The article presents the results of studies carried out at assembling two branches of science such as the chemistry of heterocyclic compounds and the chemistry of step-growth polymerization. 2,4-Dimethyl-3,5diethoxycarbonylpyrrole (Knorr pyrrole) was synthesized by a series of successive transformations. 2,4-Dimethylpyrrole-3,5-dicarboxylic acid was obtained by Knorr pyrrole hydrolysis, optimal conditions for reaction were chosen. The process was shown to be completed within an hour and a half in an alcoholalkaline medium. A new polyester based on 2,4-dimethylpyrrole-3,5-dicarboxylic acid and ethylene glycol was synthesized by a polyesterification reaction. The physicochemical characteristics of the polymer obtained were established. Light-scattering method was used to determine the mass-average molar mass of the polyester, which turned out to be equal to 5263. The good convergence of the data calculated and the reproducibility of the experiment for determining the turbidity of dilute polymer solutions by turbidimetric method indicates the reliability of the results. Analysis of the structure and physical and chemical properties of the polymer synthesized suggests that a polyester based on 2,4-dimethylpyrrole-3,5-dicarboxylic acid and ethylene glycol can be used as a component of alkyd resins potentially possessing biological activity.
\end{abstract}

Keywords: Knorr pyrrole, 2,4-dimethylpyrrole-3,5-dicarboxylic acid, polyesterification, polyester, turbidimetry.

The chemistry of heterocyclic compounds is of particular interest for scientists as these compounds have other atoms of the elements of the periodic system in addition to the carbon and hydrogen atoms in their structure [1]. This is due to the special properties of the corresponding compounds. These properties include fungicidal, acaricidal ones, different types of pharmacological activity, and new optical properties of heterocyclic compounds, the application of which is possible in all spheres of human activities.

The presence of heteroatoms in molecules such as nitrogen particularly leads to a decrease in toxicity and an increase in the high physiological activity of organic compounds. Their heterocyclic derivatives show more effective biologically active properties in comparison with aliphatic ones [2].

Compounds referring to pyrroles - five-membered nitrogen containing cyclic molecules — constantly attract the researchers' attention despite the fact that Knorr synthesis is known from the end of XIX century.

Pyrroles and their derivatives are structurally important heterocycles used in pharmaceuticals, natural products, catalysts, pesticides, dyes and conducting polymers [3]. Synthesizing polysubstituted pyrroles is often challenging and current methods, like the Paal-Knorr reaction, often results in low atom economy in which two oxygen atoms are lost per pyrrole ring produced and/or two water molecules are released as a byproduct.

Multifunctional derivatives of Knorr pyrrole are interesting for organic synthesis and as potential monomers as well.

The aim of present work is synthesis of disubstituted acyl derivatives of Knorr pyrrole for their introduction in polyesterification for obtaining $\mathrm{N}$-containing polyesters which can potentially possess valuable properties.

For obtaining starting material for step- growth polymerization firstly we synthesized 2,4-dimethyl-3,5diethoxycarbonylpyrrole (Knorr pyrrole) by series of transformations. The synthetic protocol proceeds according to the following scheme:<smiles>CCOC(=O)CC(=O)C(=NO)C(C)=O</smiles> 


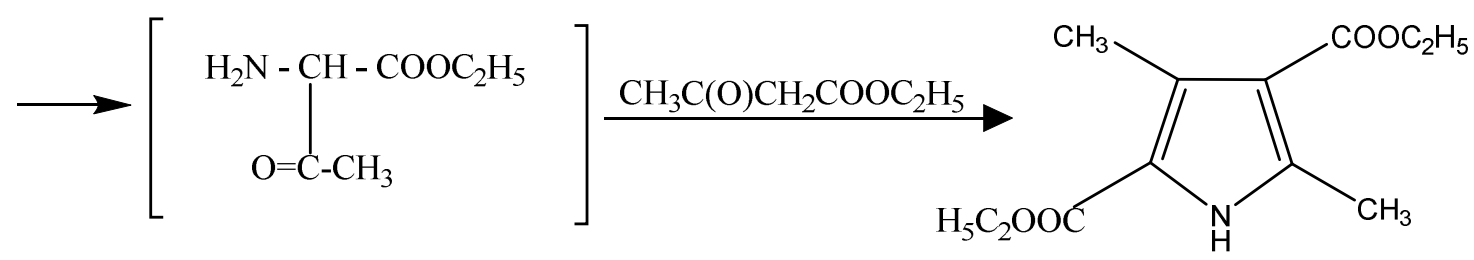

The reaction was monitored by means of the thin layer chromatography.

To continue investigations we carried out hydrolysis of ester groups of 2,4-dimethyl-3,5diethoxycarbonylpyrrole. The hydrolysis reaction is known to irreversible one in the alkaline medium and is effective for the synthesis of the corresponding acids. Therefore we hydrolyzed Knorr pyrrole in the presence of base such as sodium hydroxide. Necessary conditions were chosen, aqueous-alcohol medium was applied for completely dissolving Knorr pyrrole. Then calculated amount of sodium hydroxide was added. The reaction was completed during one and half hour. The reactive mixture was treated by concentrated hydrochloric acid for isolation of heterocyclic dicarboxylic acid.

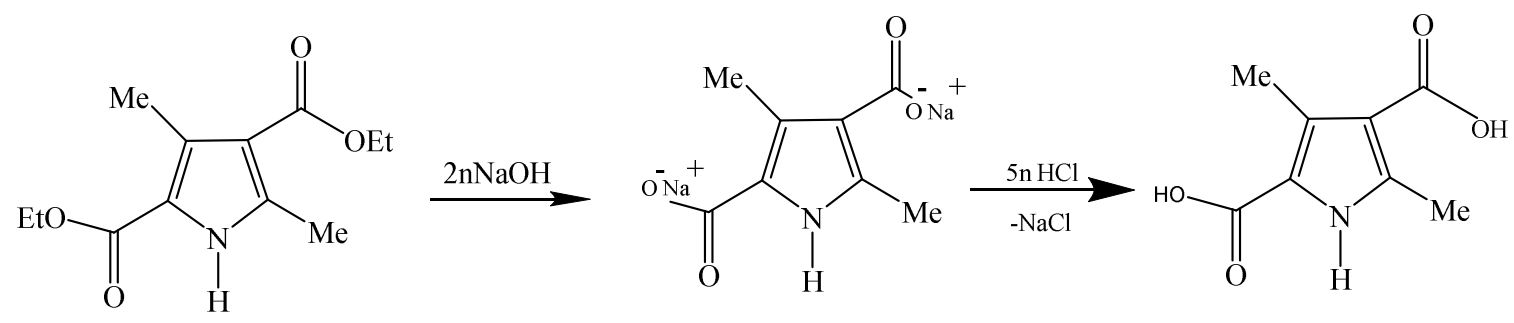

The acid obtained was completely purified by treatment of aqueous alcohol solution. Synthesized 2,4dimethylpyrrole-3,5-dicarboxylic acid is white powder, insoluble in water, melting point is equal to $205^{\circ} \mathrm{C}$.

Dicarboxylic acids are known to be monomers for step-growth polymerization to obtain various polyesters, polyamides, polyurethanes and their modified derivatives $[4,5]$.

So according to research objective we carried out polyesterification of 2,4-dimethylpyrrole-3,5dicarboxylic acid and ethylene glycol at equimolar ratio of parent materials. The process was self-catalyzed and for synthesis of high molar mass polyester it is necessary to remove water, i.e. by-product of reaction, for shifting equilibrium to obtain final polymeric product.

The process was lasted for two hours and the reaction termination was determined by the amount of water eliminated in the Dean-Stark vessel and on the basis of the IR spectrum of the product obtained. We assume that synthesis of polyester proceeds according to the following scheme.

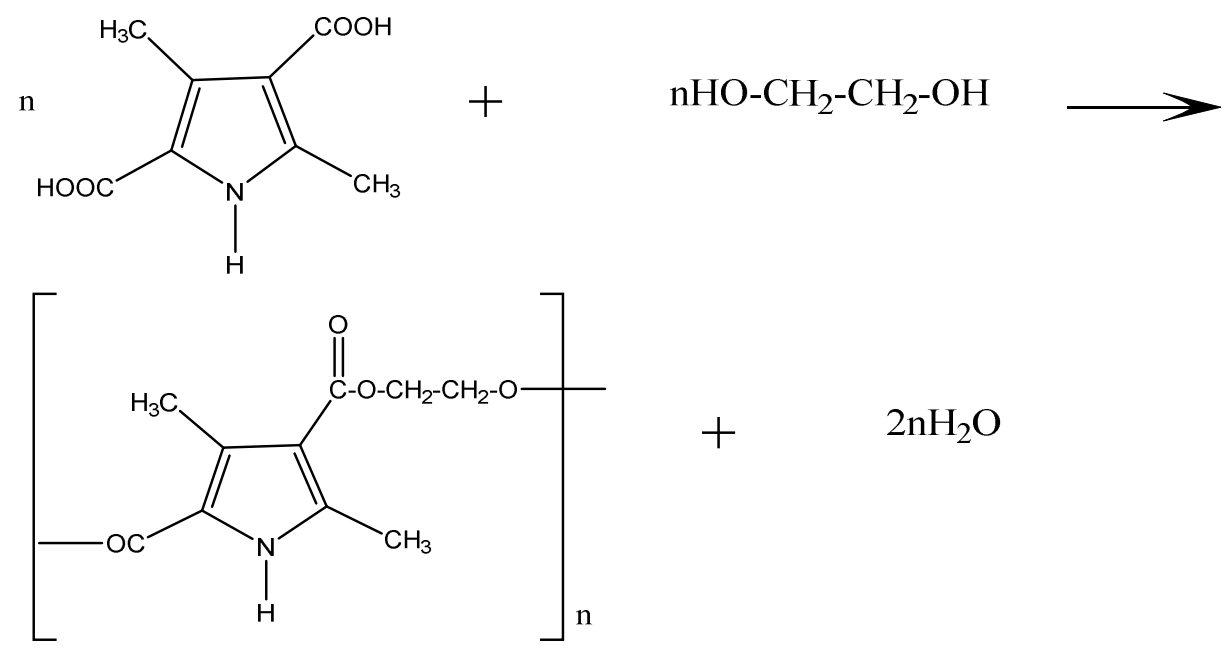

Next step of investigation was studying of properties characteristic for obtained polyester based on 2,4dimethylpyrrole-3,5-dicarboxylic acid and ethylene glycol. 
To estimate the mass-average molar mass of the polyester the Debye method (light scattering) was used [6]. Determination of turbidity of polymer solutions was carried out turbidimetrically using a 2100 AN HACH nephhelometer at $\lambda=5460 \AA$. This method is the most reliable and convenient one of the few direct methods for determining the polymers molar mass and covering an exceptionally wide range of molar masses. In addition it is a direct method for measuring the size of macromolecules in solution used for approbation and calibration of other indirect methods, in particular, hydrodynamic ones [6].

The concentration of the initial solution for determining the polymer molar mass in the wavelength region $10^{5}-10^{7}$ is of the order of $2 \cdot 10^{-3} \mathrm{~g} / \mathrm{cm}^{3}(0.2 \mathrm{~g} / \mathrm{dl})$. For preparing the solution a sample of polyester of $0.1 \mathrm{~g}$ (accurate to 0.0001$)$ was placed in a pre-weighed measuring flask $(\sim 50 \mathrm{ml})$ with ground glass stopper. Further the sample was dissolved in an increasing volume of thoroughly purified and repeatedly distilled solvent, finished to the graduating mark and weighed. The concentration of the solution $C_{1}\left(\mathrm{~g} / \mathrm{cm}^{3}\right)$ was calculated by the formula (1):

$$
C_{1}=\frac{m_{p}}{m_{s}} \rho,
$$

where $m_{p}$ - is polymer mass, $\mathrm{g} ; \rho-$ is solvent density, $\mathrm{g} / \mathrm{cm}^{3} ; m_{s}$ - is solvent mass, $\mathrm{g}$.

Then $30 \mathrm{ml}$ of the prepared solution was transferred to a cuvette of the instrument, the turbidity of the solution in NEPH units and the refractive index were determined up to full reproducibility. A series of solutions was prepared from the available solution by successively diluting an aliquot $(\sim 30 \mathrm{ml})$ of each previous solution to $50 \mathrm{ml}$ in a volumetric flask, turbidity and refractive indices were determined. The concentration of the subsequent solutions was calculated according to the formula (1).

In continuation of the research the division scale of nephelometer $(\beta)$ was determined according to formula (2):

$$
\beta=\frac{R_{90}^{\prime}}{\tau\left(\frac{n}{n_{1}}\right)^{2}} .
$$

Further the reduced intensity of polymer solutions $\left(R_{90}^{\prime}\right)$ was calculated by substituting the values in the formula (3):

$$
R_{90}^{\prime}=\beta\left(N E P H_{\text {solution }}-N E P H_{\text {solvent }}\right) \text {. }
$$

The constant value $(H)$ was calculated by means of formula (4):

$$
H=\frac{32(3,14)^{3} n_{0}^{2}(\Delta n / \Delta C)^{2}}{3 \lambda^{4} N_{\mathrm{A}}} .
$$

\begin{tabular}{|c|c|c|c|c|c|c|}
\hline$C \cdot 10^{-3}, \mathrm{~g} / \mathrm{cm}^{3}$ & $\tau_{N E P H}$ & $\beta_{N E P H}, 10^{-6}$ & $R_{90}^{\prime}, 10^{-6}$ & $H_{N E P H}, 10^{-3}$ & $H C / R_{90}, 10^{-3}$ & $n_{20}^{d}$ \\
\hline 2.0644 & 20.70 & \multirow{6}{*}{22.79} & 0.4582 & \multirow{6}{*}{217.969} & 0.0009 & 1.3782 \\
\hline 1.0322 & 14.10 & & 0.3077 & & 0.0007 & 1.3779 \\
\hline 0.5161 & 10.10 & & 0.2165 & & 0.0005 & 1.3770 \\
\hline 0.2580 & 6.98 & & 0.1455 & & 0.0003 & 1.3770 \\
\hline 0.1290 & 5.72 & & 0.1169 & & 0.0002 & 1.3765 \\
\hline 0.0645 & 3.90 & & 0.0752 & & 0.0001 & 1.3760 \\
\hline
\end{tabular}

The obtained data for measurements and calculations are presented in the Table.

$\mathrm{Tab} l \mathrm{e}$

\section{Results of turbidimetric measurements and calculations}

Based on the calculated values, a plot of the dependence $\frac{H C}{R_{90}^{\prime}}=f(C)$ was made (see Fig.). 


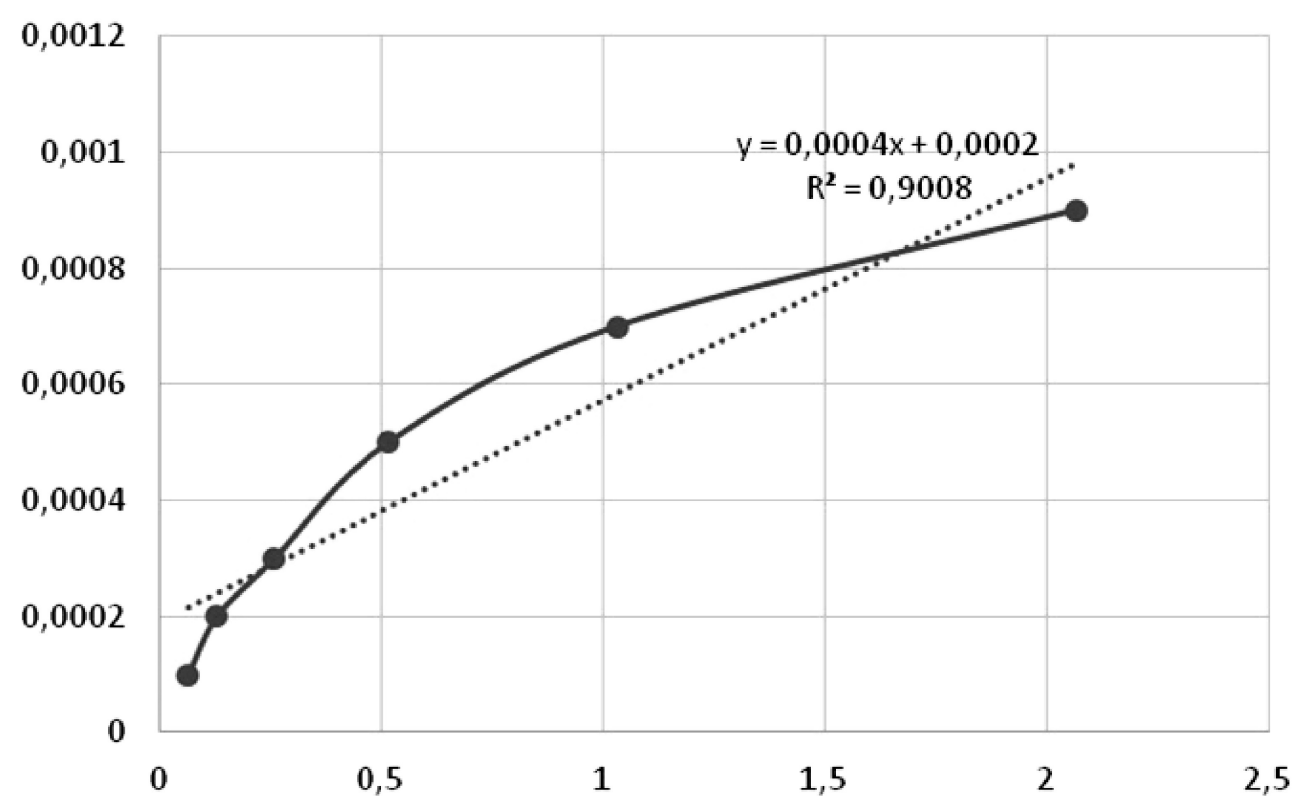

Figure. Dependence of $\frac{H C}{R_{90}^{\prime}}$ on concentration of polymer $\left(C, 10^{-3}, \mathrm{~g} / \mathrm{cm}^{3}\right)$

Extrapolating the resulting straight line to $C$ leading to 0 , we obtained a segment corresponding to limiting meaning of $\frac{H C}{R_{90}^{\prime}}=\frac{1}{M_{w}}$. According to the plot datum the value $\frac{1}{M_{w}}$ is equal to 0.00019 , so mass-average molar mass of the polyester obtained is equal to 5263. Determination of polyester solubility shows that it is soluble in organic solvents and partially soluble in aqueous alcohol mixture.

So we conclude that novel polyester based on Knorr pyrrole derivative such as 2,4-dimethylpyrrole-3,5dicarboxylic acid and well-known monomer such as ethylene glycol was obtained by step-growth polymerization. Molar mass of polymer synthesized was determined by light-scattering method. The presence of fivemembered heterocycle containing nitrogen, ester and methylene groups let us assume that such polyesters can exhibit biological activity and other valuable properties.

\section{References}

1 Jackson, A.H., Artico, M., Anderson, H.J., Loader, C. E., Gossauer, L., Nesvadba, P., \& Dennis N. (1990). Reactivity of $1 H$ Pyrrole Ring System. The Chemistry of Heterocyclic Compounds, 48(1), 295-299.

2 Raposo, M.M.M. (2007). Recent developments in the chemistry of 2-thienylpyrroles: synthesis, reactivity and applications. Targets in Heterocyclic Systems: Chemistry and Properties, 11, 122-154.

3 Zuniga, O.M.P., Sathicq, A. G., Zambrano, J. J.M., \& Romanelli, G.P. (2017). Green Synthesis of Pyrrole Derivatives. Current Organic Synthesis, 14(6), 865-888.

4 Abaidildin, T.S., Sugralina, L.M., Salkeeva, L.K., Minaeva, Ye.V., Taishibekova, Ye.K., Omasheva, A.V., \& Salkeeva, A.K. (2017). Synthesis of Polyurethane Elastomers and Investigation of their Physical and Mechanical Properties. Education and Science without Borders, 15(1), 97 - 99.

5 Sugralina, L.M., Rozhkovoy, I.Ye., Salkeeva, L.K., Minaeva, Ye.V., Taishibekova, Ye.K., Omasheva, A.V., \& Salkeeva, A.K. (2017). Phenolytical Modification of Polyurethane Elastomers as a Method of Obtaining Multifunctional Additives for Road Coal Tar Bitumen. Bulletin of the Karaganda University. Chemistry, 2(86), 30-34. $1-40$.

6 Wyatt, Ph. J. (1993). Light scattering and the absolute characterization of macro molecules. Analytica Chimica Acta, 272(1), 
Л.М. Сугралина, А.В. Омашева, Л.К. Сәлкеева, А.С. Олжабаева, Е.В. Минаева, Е.К. Тайшибекова, А.К. Сәлкеева, Г.Г. Байкенова

\title{
Азотқұрамды гетероциклдердің негізіндегі жаңа күрделі полиэфирлер: синтезі және зерттелуі
}

\begin{abstract}
Мақалада екі ғылымның - гетероциклді қосылыстар химиясы мен поликонденсациялық процестер химиясының - қиылысуындағы зерттеу нәтижелері келтірілген. 2,4-Диметил-3,5-диэтоксикарбонилпиррол (Кнорр пирролы) ілеспелі айналулар қатарымен синтезделді. 2,4-диметилпиррол-3,5дикарбон қышқылы Кнорр пирролын гидролиздеу арқылы алынды. Процес спирт-сілтілі ортада біржарым сағаттың ішінде толығымен аяқталатыны көрсетілді. Жаңа күрделі эфир 2,4-диметилпиррол-3,5-дикарбон қышқылы мен этиленгликольдің негізінде полиэтерификациялау реакциясы арқылы синтезделді. Алынған полимерлердің физикалық-химиялық сипаттамалары анықталды. Күрделі эфирдің ортамассалық молекулалық массасы жарықшашу әдісі арқылы анықталып, 5263 тең екені көрсетілді. Есептеу мәліметтері мен турбидиметрлік әдіспен сұйытылған полимер ерітінділерін бұлдырлығын анықтау бойынша тәжірибе мәліметтерінің сәйкестігі нәтижелердің нақтылығын көрсетті. Синтезделген полимердің физикалық-химиялық қасиеттері мен құрылымын сараптау 2,4диметилпиррол-3,5-дикарбон қышқылы мен этиленгликольдің негізіндегі күрделі полиэфирдің биологиялық белсенділікке ие алкидті шайырлардың компоненті ретінде қолдануының мүмкіндігін тұжырымдады.
\end{abstract}

Кілm сөздер: Кнорр пирролы, 2,4-диметилпиррол-3,5-дикарбон қышқылы, полиэтерификациялау, күрделі полиэфир, турбидиметрлік.

\section{Л.М. Сугралина, А.В. Омашева, Л.К. Салькеева, А.С. Олжабаева, Е.В. Минаева, Е.К. Тайшибекова, А.К. Салькеева, Г.Г. Байкенова \\ Новые сложные полиэфиры на основе азотсодержащих гетероциклов: синтез и исследование}

\begin{abstract}
В статье представлены результаты исследований, выполненных на стыке двух наук - химии гетероциклических соединений и химии поликонденсационных процессов. 2,4-Диметил-3,5-диэтоксикарбонилпиррол (пиррол Кнорра) был синтезирован рядом последовательных превращений. Гидролизом пиррола Кнорра была получена 2,4-диметилпиррол-3,5-дикарбоновая кислота, подобраны оптимальные условия проведения реакции. Показано, что процесс полностью завершается в течение полутора часов в спиртово-щелочной среде. Новый сложный полиэфир на основе 2,4-диметилпиррол-3,5дикарбоновой кислоты и этиленгликоля был синтезирован реакцией полиэтерификации. Были установлены физико-химические характеристики полученного полимера. Методом светорассеяния была определена среднемассовая молекулярная масса сложного полиэфира, которая оказалась равной 5263. Хорошая сходимость расчетных данных и воспроизводимость эксперимента по определению мутности разбавленных растворов полимера турбидиметрическим методом указывают на достоверность результатов. Анализ структуры и физико-химических свойств синтезированного полимера предполагает, что сложный полиэфир на основе 2,4-диметилпиррол-3,5-дикарбоновой кислоты и этиленгликоля может быть использован в качестве компонента алкидных смол, потенциально обладающих биологической активностью.
\end{abstract}

Ключевые слова: пиррол Кнорра, 2,4-диметилпиррол-3,5-дикарбоновая кислота, полиэтерификация, сложный полиэфир, турбидиметрия. 